\title{
SURVIVAL FOLLOWING TRAUMATIC TETRAPLEGIA
}

By D. G. Sneddon, B.Sc., M.B., B.S., (Hons) and Sir George Bedbrook, O.B.E., OSt.J., Hon. M.D.(W.A.), M.S.(Melb.), D.P.R.M.(Syd.), F.R.C.S., F.R.A.C.S. Royal Perth Rehabilitation Hospital, Shenton Park, Western Australia

\begin{abstract}
A retrospective study of patients sustaining traumatic tetraplegia is presented. Survival is correlated with the level of the lesion and the age of patient at which the injury was sustained.
\end{abstract}

Key words: Traumatic tetraplegia; Acute survival; Long-term survival; Complete lesion; Incomplete lesion.

\section{Introduction}

WITH the improvement in management of spinal injuries, including the early transfer of patients to a specialised unit, the intensive care facilities available and the involvement of a full range of specialist services, especially microbiologists and urologists, patients could anticipate an increasingly improved prognosis. The likelihood of long-term survival has important implications in the long-term planning for facilities, including home nursing facilities and permanent accommodation areas for an increasing number of patients, as well as medico-legal importance.

\section{Clinical Material}

In order to examine prognosis following such an injury, a retrospective study was made from the records of the Spinal Unit of Royal Perth Rehabilitation Hospital to determine prognosis on a long-term basis following traumatic tetraplegia. All patients studied in this review had traumatic tetraplegia on admission and have been divided into two groups: those at the $\mathrm{C}_{4}$ level and above and those at the $\mathrm{C}_{5}$ level and below. This study differentiates these groups but does not look at levels at and below TI. No patient admitted subsequent to December 1978 has been included in this study. There has been no uniformity in the literature as to what time interval constitutes the acute phase following injury. Hardy (I976) reported mortality figures after time intervals of I week and I year.

To enable comparison with previous studies, mortality at I week, 6 weeks, I 2 weeks and I year is tabulated and long-term survival for those patients surviving more than I year following injury is reviewed. All patients presenting with acute tetraplegia are included in the study, including those who sustained multiple trauma.

Most published series have not related survival to the level of the cervical lesion. Young and Harris (1980) studied mortality in patients with high cervical injury $\mathrm{CI}_{-}-\mathrm{C}_{4}$ but their cases were admitted on an average of 49 days from injury.

\section{Acute Survival}

\section{Complete Lesions Above $\mathrm{C}_{5}$}

Twenty-five patients were in this group, one lost to follow-up, leaving 24 in total. The acute mortality rate varied with the age of the patient at the time of injury. 


\section{TABLE I}

Number of patients dying at varying intervals after injury related to age at injury, for complete lesions above $\mathrm{C}_{5}$ level

\begin{tabular}{lccccc}
\hline $\begin{array}{c}\text { Age } \\
\text { (years) }\end{array}$ & $\begin{array}{c}\text { No. of } \\
\text { patients }\end{array}$ & $\begin{array}{r}\text { No. dead } \\
\text { at I week }\end{array}$ & $\begin{array}{c}\text { No. dead } \\
\text { at } 6 \text { weeks }\end{array}$ & $\begin{array}{c}\text { No. dead } \\
\text { at } 3 \text { months }\end{array}$ & $\begin{array}{c}\text { total dead } \\
\text { at I year }\end{array}$ \\
\hline I 5-24 & I2 & I & 2 & 2 & 3 \\
$25-34$ & 5 & I & I & I & I \\
$35-44$ & 3 & - & - & - & - \\
$45+$ year & 4 & I & 3 & 3 & 3 \\
\hline
\end{tabular}

Table I shows mortality after I week, 6 weeks, 3 months and I year after injury, related to age at injury. Six of the seven patients that died within I year of injury were admitted to the Spinal Unit within 24 hours of injury. The other case was not admitted until 4 days following injury.

\section{Long-Term Survival}

Seventeen patients surviving the first year remained for long-term follow-up. Five patients have survived between I and 4 years, with two dying in this period. Three have survived between 5 and 9 years with no deaths in this period and six have survived between IO and I4 years with I death in this time interval.

No patient sustaining a complete lesion above $\mathrm{C}_{5}$ over the age of 45 years has yet survived 5 years.

Table II shows long-term mortality related to age.

\section{TABLE II}

Survival at varying time intervals after injury related to age for complete lesions above $\mathrm{C}_{5}$ level

\begin{tabular}{|c|c|c|c|c|c|c|c|c|c|c|}
\hline \multirow{3}{*}{$\begin{array}{l}\text { Survival in } \\
\text { years } \\
\text { following } \\
\text { injury }\end{array}$} & \multicolumn{10}{|c|}{ Age of patient at injury } \\
\hline & \multicolumn{2}{|c|}{$\begin{array}{l}\text { I5-24 } \\
\text { years }\end{array}$} & \multicolumn{2}{|c|}{$\begin{array}{c}25-34 \\
\text { years }\end{array}$} & \multicolumn{2}{|c|}{$\begin{array}{c}35-44 \\
\text { years }\end{array}$} & \multicolumn{2}{|c|}{$\begin{array}{l}45+ \\
\text { years }\end{array}$} & \multicolumn{2}{|c|}{ Total } \\
\hline & Alive & Dead & Alive & Dead & Alive & Dead & Alive & Dead & Alive & Dead \\
\hline$I-4$ & 3 & I & I & I & - & - & I & - & 5 & 2 \\
\hline $5-9$ & 2 & - & I & - & - & 一 & 一 & 一 & 3 & - \\
\hline IO-I 4 & 3 & - & I & - & 2 & I & 一 & - & 6 & I \\
\hline
\end{tabular}

\section{Acute Survival}

\section{Complete Lesions Below $C_{5}$}

There were IOI patients in this group of whom six were lost to follow-up within the first year, leaving 95 patients. The mortality rate during the first year increases rapidly with increasing age over 45 years. Of the 24 patients that died within I year, 22 were admitted within 24 hours of injury to the Spinal Unit, and the other two were admitted at 4 days and 6 days post injury.

Table III shows mortality after I week, 6 weeks, 3 months and I year after injury related to age at injury. 


\section{TABLE III}

Number of patients dying at varying intervals after injury related to age at injury, for complete lesions below $\mathrm{C}_{5}$

\begin{tabular}{cccccc}
\hline $\begin{array}{c}\text { Age } \\
\text { (Years) }\end{array}$ & $\begin{array}{c}\text { No. of } \\
\text { patients }\end{array}$ & $\begin{array}{c}\text { No. dead } \\
\text { at I week }\end{array}$ & $\begin{array}{c}\text { No. dead } \\
\text { at 6 weeks }\end{array}$ & $\begin{array}{c}\text { No. dead } \\
\text { at 3 months }\end{array}$ & $\begin{array}{c}\text { No. dead } \\
\text { at I year }\end{array}$ \\
I5-24 & 4I & 2 & 2 & 3 & 3 \\
$25-34$ & I3 & - & - & - & I \\
$35-44$ & I2 & - & - & I & I \\
$45-54$ & I0 & - & 4 & 4 & 5 \\
$55+$ & I9 & 3 & 5 & 9 & I 4 \\
\hline
\end{tabular}

\section{Long-Term Survival}

A further nine patients were lost to follow-up after I year leaving 62 patients for long-term review. Twenty-three patients survived between I and 4 years and six died in this period.

Nine patients survived between 5 and 9 years with four deaths in this period.

Six patients survived between Io and I4 years with one death in this period.

Ten patients survived between I 5 and I 9 years with no deaths occurring in this period and three have survived more than 20 years.

Table IV shows long-term mortality related to age.

\section{Incomplete Lesions Above $\mathbf{C}_{5}$}

Sixty patients were admitted with incomplete lesions of the cervical spinal cord in the same period, of whom seven died within I year.

All deaths occurred in patients over the age of 45 years. In this older age group $7 / 26$ died within I year.

Table V shows mortality after I week, 6 weeks, and I year after injury.

\section{Incomplete Lesions Below $\mathbf{C}_{5}$}

One hundred and seventy-seven patients were admitted with incomplete cervical cord lesions below the level of $\mathrm{C}_{5}$. There were eight deaths in the first year, again seven of these eight were in age group 45 and over.

Table VI shows mortality after I week, 6 weeks and I year after injury.

\section{Discussion}

Cervical spinal cord injury of traumatic origin is associated with a high mortality rate, both in the first year and subsequently. The records of 363 patients with cervical injuries complete and incomplete were reviewed, of whom 46 died within I year of injury.

The age of the patient at the time of injury is crucial, patients over the age of 45 years fare poorly.

In a review by Hardy (1976), of 30 cases of complete quadriplegia who were over the age of 45 years at the time of accident, I 2 died within I week and I6 within I year. 


\section{TABLE IV}

Long-Term Survival Lesion Below $\mathrm{C}_{5}$

Survival at varying time intervals after injury related to age for complete lesions below $\mathrm{C}_{5}$ level

\begin{tabular}{|c|c|c|c|c|c|c|c|c|c|c|c|c|}
\hline \multicolumn{13}{|c|}{ Age of patient at injury } \\
\hline \multirow{2}{*}{$\begin{array}{c}\text { Survival in } \\
\text { years } \\
\text { following } \\
\text { injury }\end{array}$} & \multicolumn{2}{|c|}{$\begin{array}{l}\text { No. of } \\
\text { Patients }\end{array}$} & \multicolumn{2}{|c|}{$\begin{array}{l}\text { I 5-24 } \\
\text { years }\end{array}$} & \multicolumn{2}{|c|}{$\begin{array}{l}25-34 \\
\text { years }\end{array}$} & \multicolumn{2}{|c|}{$\begin{array}{l}35-44 \\
\text { years }\end{array}$} & \multicolumn{2}{|c|}{$\begin{array}{l}45-54 \\
\text { years }\end{array}$} & \multicolumn{2}{|c|}{$\begin{array}{c}55^{-} \\
\text {years }\end{array}$} \\
\hline & Alive & Dead & Alive & Dead & Alive & Dead & Alive & Dead & Alive & Dead & Alive & Dead \\
\hline $\mathrm{I}-4$ & 23 & 6 & $\mathrm{I} 2$ & I & 4 & I & 3 & I & 2 & I & 2 & 2 \\
\hline $5-9$ & 9 & 4 & 7 & I & 2 & I & - & I & 一 & I & - & 一 \\
\hline IO-I4 & 6 & I & 5 & 一 & 一 & - & $\mathrm{I}$ & - & 一 & - & 一 & I \\
\hline I5-I9 & IO & - & 6 & - & 3 & - & 一 & - & I & - & 一 & - \\
\hline $20-$ & 3 & - & 2 & - & I & 一 & 一 & 一 & 一 & - & - & 一 \\
\hline
\end{tabular}


TABLE V

Number of patients dying at varying intervals after injury related to age at injury for incomplete lesions above $\mathrm{C}_{5}$ level

\begin{tabular}{ccccc}
\hline $\begin{array}{c}\text { Age } \\
\text { (Years) }\end{array}$ & $\begin{array}{c}\text { No. of } \\
\text { patients }\end{array}$ & $\begin{array}{c}\text { No. dead } \\
\text { at I week }\end{array}$ & $\begin{array}{c}\text { No. dead } \\
\text { at 6 weeks }\end{array}$ & $\begin{array}{c}\text { No. dead } \\
\text { at I year }\end{array}$ \\
$\begin{array}{cccc}\text { I5-44 } \\
45+\end{array}$ & 34 & - & - & - \\
\hline
\end{tabular}

\section{TABLE VI}

Number of patients dying at varying intervals after injury related to age at injury for incomplete lesions below $\mathrm{C}_{5}$ level

\begin{tabular}{ccccc}
\hline $\begin{array}{c}\text { Age } \\
\text { (Years) }\end{array}$ & $\begin{array}{c}\text { No. of } \\
\text { Patients }\end{array}$ & $\begin{array}{c}\text { No. dead } \\
\text { at I week }\end{array}$ & $\begin{array}{c}\text { No. dead } \\
\text { at 6 weeks }\end{array}$ & $\begin{array}{c}\text { No. dead } \\
\text { at I year }\end{array}$ \\
I5-44 & I22 & - & - & I \\
45 +years & 55 & 0 & I & 7 \\
\hline
\end{tabular}

In this study 33 patients over the age of 45 were completely quadriplegic. Four died within I week and 22 died within I year. The difference in mortality rates after I week may be due to the fact that all but two of the patients in the present series were admitted within 24 hours to the Spinal Unit.

In the same review by Hardy (1976) of cases of complete tetraplegia under the age of 45 years, of 88 cases ten died within I week and a further nine died within the next 3 months.

In the present series for a similar group of 86 patients, four died within I week and a further 13 within the next 3 months.

In a series of incomplete lesions over the age of 45 years, Hardy in a series of I 25 found that 12 died within I week and a further 12 within a year. In the present series there were $8 \mathrm{I}$ patients. One died within I week and a further seven died within I year.

Comparisons of mortality figures between series from differing authors are difficult, due to the different patient populations. In one study (Geisler, I977) only patients participating in a rehabilitation programme were included, and in another (Young \& Harris, I980) patients were admitted on an average of 49 days from injury.

Tables VII and VIII show comparison between the present series and that of Hardy (1976) for patients over 45 years and under 45 years respectively.

As the patient population is similar in Hardy's series in that it comprises patients admitted to a Spinal Unit within hours or days of the injury, comparison is allowable. In the series by Hardy, patients were admitted to the Spinal Unit 'within a matter of days', and in the present series, all but two or three were admitted within 24 hours.

The time lapse between accident and admission to a Spinal Unit may be important in relation to those deaths occurring within the first week, but the number of deaths occurring within the first 3 months were similar. Hardy 19/88, present author $\mathrm{I} 7 / 86$, for patients under 45 years. 


\section{TABle VII}

Comparison between this series and that published by Hardy (1976) of survival of patients over the age of 45 years

\begin{tabular}{lcccc}
\hline & \multicolumn{2}{c}{ Present authors } & \multicolumn{2}{c}{ Hardy } \\
& $\begin{array}{l}\text { No. dead } \\
\text { in I week }\end{array}$ & $\begin{array}{c}\text { No. dead } \\
\text { in I year }\end{array}$ & $\begin{array}{c}\text { No. dead } \\
\text { in I week }\end{array}$ & $\begin{array}{l}\text { No. dead } \\
\text { in I year }\end{array}$ \\
Complete & $4 / 33$ & $22 / 33$ & $12 / 30$ & I6/30 \\
Incomplete & I/8I & $8 / 8 \mathrm{I}$ & $12 / \mathrm{I} 25$ & $24 / \mathrm{I} 25$ \\
\hline
\end{tabular}

\section{TABLE VIII}

Comparison between present series and that published by Hardy of survival of patients under the age of 45 years

\begin{tabular}{|c|c|c|c|}
\hline & \multicolumn{2}{|c|}{ Present authors } & Hardy (I976) \\
\hline & $\begin{array}{l}\text { No. dead } \\
\text { in I week }\end{array}$ & $\begin{array}{l}\text { No. dead } \\
\text { in } 3 \text { months }\end{array}$ & $\begin{array}{l}\text { No. dead No. dead } \\
\text { in I week in } 3 \text { months }\end{array}$ \\
\hline Complete & 486 & $17 / 86$ & IO/88 \\
\hline
\end{tabular}

Similar studies (Hardy, I976; Kraus, I979; Young, I980) have drawn attention to the high mortality rates in those patients aged 45 years or more at the time of injury. In the present study the mortality rates at I week, 6 weeks and I year are shown in Table IX.

In a review of tetraplegia in the elderly (60 years + ) Watson (1976) found a mortality rate of 80 per cent in the acute phase, although he did not define the length of his acute time interval in patients with complete tetraplegia.

In this series it is also apparent that the high mortality rate above 45 years continues long after the acute phase, with eight out of 28 patients dying between

\section{TABLE IX}

\section{Deaths}

No. of

Patients I week 6 weeks I year

Below 45 years

Complete above $\mathrm{C}_{5}$ Incomplete above $\mathrm{C}_{5}$ Complete below $\mathrm{C}_{5}$

Incomplete below $\mathrm{C}_{5}$

$\begin{array}{rccc}\text { I8 } & 2(\mathrm{II} \%) & 3(\mathrm{I} 7 \%) & 4(22 \%) \\ 34 & -2(3 \%) & 2(3 \%) & 5(8) \% \\ 66 & - & -\end{array}$

Above 45 years

Complete above $\mathrm{C}_{5}$

Incomplete above $\mathrm{C}_{5}$

Complete below $\mathrm{C}_{5}$

Incomplete below $\mathrm{C}_{5}$

4
26
29
55

I $(25 \%)$
I $(4 \%)$
$3(10 \%)$
$-(0 \%)$

$3(75 \%)$ 
I and 4 years after injury and four out of 12 dying between 5 and 9 years following injury.

\section{Conclusions}

I. The prognosis for patients over the age of 45 years sustaining traumatic tetraplegia is materially worse than for those under this age.

2. Complete lesions above $\mathrm{C}_{5}$ are associated with a high mortality rate and for those patients over 45 years, 75 per cent die in the first year.

3. The mortality associated with an incomplete lesion above $\mathrm{C}_{5}$ in the older population is as high as that for a complete lesion at the same level in a younger population.

\section{SUMMARY}

The records of 363 patients presenting to the Spinal Unit of Royal Perth Rehabilitation Hospital with traumatic tetraplegia are reviewed. Mortality rates in both short and long terms are tabulated and correlated with the level of the lesion, age of the patient at the time of injury and completeness of the lesion. The mortality rate for patients sustaining a complete lesion above $\mathrm{C}_{5}$ at the end of $\mathrm{I}$ year after injury was 20 per cent if under the age of 45 years and 75 per cent if over the age of 45 years. The mortality rate of patients sustaining a complete lesion below C5 at the end of I year after injury was 8 per cent if under the age of 45 years and 66 per cent if over the age of 45 years.

\section{RÉSUMÉ}

Les dossiers de 363 malades qui se sont presentes au Spinal Unit du Royal Perth Rehabilitation Hospital avec de la quadriplégie traumatique ont été révisé. Les taux de la mortalité à court terme et à long terme ont été classifié et ont été mis en corrélation avec le niveau de la lesion, l'age du malade quand il s'était bléssé et l'état complet de la lesion. Le taux de la mortalité des malades avec une lésion complète au dessus de $\mathrm{C}_{5}$ après une anneé d'être bléssé était $20 \%$ si le malade avait moins de 45 ans et $75 \%$ si le malade avait plus de 45 ans. Le taux de mortalité des malades avec une lésion complete au dessous de $\mathrm{C}_{5}$ après une année d'être bléssé était $8 \%$ si le malade avait moins de 45 ans et $66 \%$ si le malade avait plus de 45 ans.

\section{ZUSAMMENFASSUNG}

Die Krankheitsgeschichten von 363 patienten mit traumatischer para- oder Tetraplegie, die an der Wirbelsaeulenabteilung des Royal Perth Rehabilitation Hospital behandelt worden sind, werden zusammengefasst. Kurz- sowie langfristige Sterblichkeits-ziffern werden tabellarisch dargestellt und nach dem Sitz der Verletzung, dem Alter des Patienten zur Zeit der Verletzung und dem Ausmass der Verletzung eingeordnet. Unter Patienten mit vollstaendigem Bruch hoeher als $Z_{5}$ betrug die Sterblichkeitsrate ein Jahr nach der Verletzung $20 \%$ fuer Patienten unter 45 Jahre, und $75 \%$ fuer Patienten ueber 45 Jahre. War der vollstaendige Bruch niedriger als $Z_{5}$, so betrug die Sterblichkeitsrate ein Jahr nach der Verletzung $8 \%$ fuer Patienten unter 45 Jahre, und 66\% fuer Patienten ueber 45 Jahre.

\section{REFERENCES}

Geisler, W. O. (1977). Survival in traumatic transverse myelitis. Paraplegia, 14, 262-272. HARDy, A. G. (I976). Survival periods in traumatic paraplegia. Paraplegia, 14, 4I-46.

Kraus, J. F. (1979). Survival with an acute spinal cord injury. F. Chron. Dis., 32, 269-283. Watson, N. (1976). Pattern of spinal cord injury in the elderly. Paraplegia, 14, 36-40.

Young, J. S. (1980). High cervical (CI-C4) spinal cord injury. Spinal Cord Injury Digest, 7-I6. 